\title{
Germination and field emergence potential of soybean land races vs improved varieties under different sowing dates
}

\author{
Asim Muhammad*, Inamullah, Hamayoon Khan and Muhammad Arif \\ Department of Agronomy, Faculty of Crop production Sciences, The University of Agricultural, Peshawar, Khyber \\ Pakhtunkhwa-Pakistan. \\ *Corresponding author's email: asimmuh@aup.edu.pk
}

Citation

Asim Muhammad, Inamullah, Hamayoon Khan and Muhammad Arif. Germination and field emergence potential of soybean land races vs improved varieties under different sowing dates. Pure and Applied Biology. Vol. 6, Issue 1, pp146-152. http://dx.doi.org/10.19045/bspab.2017.60007

\begin{tabular}{llll}
\hline \hline Received: 14/10/2016 & Revised: 06/01/2017 & Accepted: 09/01/2017 & Online First: 12/01/2017 \\
\hline
\end{tabular}

\section{Abstract}

Poor seed quality resulting in the establishment of poor stand which is the major problem of production in the cultivation of soybean. The objectives behind study were to evaluate the standard germination, field emergence and field emergence index of the seeds obtained from three land races (Kulat brown, Kulat white, Mothi) and two improved varieties (NARC-II, Swat84) of soybean sown at four different dates at monthly interval from April to July during 2004, 2005 at New Developmental Farm, Agriculture University Peshawar. Standard germination, field emergence and field emergence index were significantly affected by sowing dates and varieties. In addition, to field emergence and field emergence index were observed to be affected by years. Sowing dates $\mathrm{x}$ varieties interactions were found significant for field emergence only. Maximum germination $(74.6 \%)$, field emergence $(60.2 \%)$ and field emergence index (79.1) were recorded for seeds harvested from May, April and April planted crops respectively. Kulat brown exhibited maximum germination (79\%), field emergence (66.1\%) and emergence index (83.6). In land races, germination, field emergence and field emergence index were detected as higher by 39, 58 and 12 percent comparatively to improved varieties. It is concluded that land races have the potential to emerge in various environmental conditions contrasted with improved varieties of soybean.

Keywords: Germination; Field emergence; Field emergence index; Soybean land races

\section{Introduction}

Soybean (Glycine max (L.) Merril) cultivation has been very fluctuating and unstable since its introduction in early sixtees [1]. One of the major constraint is the low seed vigor and viability resulting into poor stand establishment. Seed vigor is one of the most important parameters of seed quality and it has the potential to influence crop production through seedling establishment, particularly under changing environmental conditions. Measures of seed vigor on soybean (Glycine max (L.) Merril) showed that this evaluation related better to emergence in the field under stress condition than did the results from the standard 
germination test [2]. Many researchers have concluded significant correlation coefficients between laboratory results concerning evaluations of physiological potential (standard germination tests) and field emergence [3]. Many seeds germinate well under ideal laboratory conditions whereas they may fail to emerge successfully in the field [4]. Several studies $[5,6]$ proved that seed quality may be influenced due to environmental conditions during seed filling period. Seed priming has been shown to improve seed performance under sub-optimal temperature conditions [7]. Higher emergence was obtained from early planted crop [8]. Germination and emergence both are sensitive to adverse soil conditions [9]. In order to determine field emergence index different techniques have been used [10]. Sowing date is the most critically important environmental factor affecting soybean growth and development [11]. Optimum time of sowing gives favorable conditions for maximum vegetative growth which is not possible with the delayed sowing [12]. Among the various factors of crop production, improved varieties and proper sowing dates play a key role in boosting production of crops [13]. Due to the climate change and introduction of new varieties. Appropriate sowing time is essential for higher germination and production. Due to the findings of the above studies, it was considered essential to investigate and explore the germination and field emergence potential of land races and improved verities of soybean under different sowing dates.

\section{Materials and methods Experimentation}

Seeds of three indigenous land races (kulat brown, Kulat white, Mothi) were collected from Agriculture Research Station, Mingowara, Swat and two improved varieties (NARC-II, Swat-84) were collected from National Agriculture Research center,
Islamabad. These soybean varieties were sown at four sowing dates at monthly interval from April to July at New Developmental Farm, The University of Agricultural, Peshawar, Pakistan during 2004-2005 and 2005-2006 growing seasons. Each treatment was replicated four times. A sub plot size of $3 \mathrm{~m} \times 3 \mathrm{~m}$ with $3 \mathrm{~m}$ long row having six rows and $50 \mathrm{~cm}$ space between rows were kept. After harvest, the clean dry seeds of all varieties from various sowing dates in 2004 and 2005 were both tested for determining standard germination, field emergence and field emergence index in their respective years.

\section{Site description}

The site is located at $34.01^{0} \mathrm{~N}$ latitude, $71.35^{\circ}$ $\mathrm{E}$ longitudes and at an altitude of 450 meters above sea level, sixteen hundred kilometers away north of Indian Ocean. According to the physiographic zones of the province, the site lies in the agro-ecological zone $\mathrm{C}$, having warm sub humid climate with 450 to $750 \mathrm{~mm}$ annual rainfall. The soil of the experimental field was silty clay loam, with montmorilonite clay type, low in nitrogen $(0.03-0.04 \%)$ and organic matter $(0.7-0.8 \%)$ and alkaline in nature ( $\mathrm{pH} 8-8.2)$.

\section{Standard germination tests}

Standard germination tests were made according to [14]. Four lots of 100 seed each from various treatments were drawn, placed on two sheets of standard germination paper and covered with an additional sheet. The sheets were folded from the bottom and rolled loosely in a rubber band. Rolls were placed upright in wire basket covered with plastic, and placed in an incubator at $25^{\circ} \mathrm{C}$. The first and the last count were made on $7^{\text {th }}$ and $10^{\text {th }}$ day of incubation respectively. Germination is defined as the emergence and development of essential structures indicative of normal seedling under favourable conditions [14]. Normal seedlings were described, those having a vigorous primary root or a set of secondary roots sufficient to anchor the 
seedlings in the soil, a hypocotyl without open cracks or lesions, at least one attached cotyledon, one primary leaf and an intact terminal bud. Seedlings lacking these qualities were considered abnormal. Averages of the four lots were computed to determine germination percentage.

\section{Field emergence tests}

Field emergence tests were conducted on silty clay loam soil in second week of April each year. Four lots of hundred seeds each of various treatments were hand planted 3 $\mathrm{cm}$ deep with $5 \mathrm{~cm}$ plant to plant distance. Final emergence was recorded as the percentage of the number of seeds planted.

\section{Field emergence index}

Field emergence index (FEI) was calculated with the help of the formula FEI= FE/G x 100. FE is the field emergence and $\mathrm{G}$ is the standard germination. In this index the higher the values, the better the field conditions, until FEI=100. FEI was calculated according to the procedure adopted [10].

\section{Statistical analysis}

The collected data on various parameters were subjected to the analysis of variance according to split plot design [15] and means among treatments were compared using least significance difference (LSD) test at $5 \%$ level of probability $(\mathrm{P}<0.05)$. The data was analyzed with MS-Excel. For significant sowing date in soybean varieties interactions, regression analysis was also carried out.

\section{Results and discussion}

\section{Standard germination (\%)}

Statistical analysis of the data showed, that significant variations existed in standard germination among sowing dates (D) and varieties (V), for the two years average (Table 1). Standard germination was not effected by years. Maximum germination was recorded in seeds obtained from May (74.6\%) and April
(73.3\%) planting, which did not differ between themselves. However germination declined in the case of seeds from June (66.6\%) and July (59.3\%) planted crops. The relatively higher germination of the seeds obtained from April and May planted crops and lower for the months of June and July planted crops could be based on the early planted crop thereby availed sufficient time for reproductive development, seed filling and maturity comparatively to the late planted crop. Our findings are in conformity with [16] who reported that seeds from the optimum sowing dates had higher percentage of germination than the early or delayed planted crop. However some of the researchers did not observe any effect of sowing date on germination [17], while [6] reported higher germination in seeds from late planted crop [18].

Maximum germination (79\%) was recorded for Kulat brown followed by Mothi $(76.9 \%)$ and Kulat white $(75.3 \%)$. NARC-II and Swat-84 displayed minimum germination of 56.3 and $54.8 \%$ respectively. The rate of decline in germination in seeds of June and July planted crops was somewhat similar in land races and improved varieties. Germination was higher by $38.9 \%$ in land races than improved varieties. It was also noted that the higher germination percentage of land races relatively to improved varieties, was because of small seed size of land races comparatively to improved varieties (Table 2). Several reports [13-15] have confirmed that small seeded soybeans have higher germination $\%$ age than large seeded soybeans and thus non-significant $\mathrm{D} \times \mathrm{V}$ interaction was noted (Table 3). As crop seeds with high vigor are expected to germinate sooner [19] although, the late emerging crop seeds have lower competitive ability than early emerging seeds [20]. 
Table 1. Two years means for standard germination (\%), field emergence (\%) and field emergence index of soybean land races vs improved varieties as affected by sowing dates

\begin{tabular}{|c|c|c|c|c|c|c|c|c|c|c|c|c|c|c|c|}
\hline & \multicolumn{5}{|c|}{ Standard germination $(\%)$} & \multicolumn{5}{|c|}{ Field emergence $(\%)$} & \multicolumn{5}{|c|}{ Field emergence index } \\
\hline Varieties & $\begin{array}{c}\text { April } \\
2\end{array}$ & $\begin{array}{c}\text { May } \\
2 \\
\end{array}$ & $\begin{array}{c}\text { June } \\
2 \\
\end{array}$ & $\begin{array}{c}\text { July } \\
2 \\
\end{array}$ & Mean & $\begin{array}{c}\text { April } \\
2\end{array}$ & $\begin{array}{c}\text { May } \\
2 \\
\end{array}$ & $\begin{array}{c}\text { June } \\
2\end{array}$ & $\begin{array}{c}\text { July } \\
2\end{array}$ & Mean & $\begin{array}{c}\text { April } \\
2 \\
\end{array}$ & May2 & $\begin{array}{c}\text { June } \\
2 \\
\end{array}$ & $\begin{array}{c}\text { July } \\
2 \\
\end{array}$ & Mean \\
\hline $\begin{array}{c}\text { Kulat } \\
\text { brown }\end{array}$ & 85.3 & 87.3 & 74.5 & 69.1 & $79.0 \mathrm{a}$ & $79.0 \mathrm{a}$ & 71.1abc & $56.0 \mathrm{ef}$ & $58.4 \mathrm{def}$ & $66.1 \mathrm{a}$ & 93.0 & 81.8 & 74.9 & 84.6 & $83.6 \mathrm{a}$ \\
\hline $\begin{array}{l}\text { Kulat } \\
\text { white }\end{array}$ & 75.4 & 83.4 & 76.6 & 65.6 & $75.3 \mathrm{a}$ & $72.4 \mathrm{ab}$ & $64.9 \mathrm{bcd}$ & 58.4def & $53.4 \mathrm{f}$ & $62.3 \mathrm{a}$ & 85.6 & 78.3 & 76.5 & 81.0 & $80.3 \mathrm{ab}$ \\
\hline Mothi & 84.9 & 81.9 & 73.3 & 67.5 & $76.9 \mathrm{a}$ & $69.6 \mathrm{bc}$ & $62.9 \mathrm{cde}$ & $51.1 \mathrm{fg}$ & $44.0 \mathrm{gh}$ & $56.9 \mathrm{~b}$ & 82.3 & 77.0 & 69.8 & 66.2 & $73.8 \mathrm{bc}$ \\
\hline $\begin{array}{l}\text { NARC- } \\
\text { II }\end{array}$ & 61.9 & 60.4 & 55.6 & 47.4 & $56.3 b$ & $42.1 \mathrm{~h}$ & $42.1 \mathrm{~h}$ & $36.3 \mathrm{~h}$ & $37.9 \mathrm{~h}$ & $39.6 \mathrm{c}$ & 69.2 & 71.3 & 65.7 & 79.0 & $71.3 \mathrm{c}$ \\
\hline Swat-84 & 58.9 & 60.3 & 53.0 & 47.0 & $54.8 \mathrm{~b}$ & $37.8 \mathrm{~h}$ & $42.5 \mathrm{~h}$ & $36.0 \mathrm{~h}$ & $37.3 \mathrm{~h}$ & $38.4 \mathrm{c}$ & 65.2 & 70.5 & 67.9 & 79.5 & $70.8 \mathrm{c}$ \\
\hline Means & $73.3 \mathrm{a}$ & $74.6 \mathrm{a}$ & $66.6 \mathrm{~b}$ & $59.3 c$ & - & $60.2 \mathrm{a}$ & $56.7 \mathrm{a}$ & $47.6 \mathrm{~b}$ & $46.2 b$ & & $79.1 \mathrm{a}$ & $75.8 \mathrm{a}$ & $70.9 \mathrm{~b}$ & $78.1 \mathrm{a}$ & - \\
\hline $\mathrm{P} \leq 0.05$ & \multicolumn{2}{|c|}{ Dates (D) } & \multicolumn{2}{|c|}{ Varieties (V) } & $\mathrm{DxV}$ & \multicolumn{2}{|c|}{ Dates (D) } & \multicolumn{2}{|c|}{ Varieties $(\mathrm{V})$} & $\mathrm{DxV}$ & \multicolumn{2}{|c|}{ Dates (D) } & \multicolumn{2}{|c|}{ Varieties (V) } & $\mathrm{DxV}$ \\
\hline $\begin{array}{c}\text { Lsd } \\
\text { Value }\end{array}$ & \multicolumn{2}{|c|}{5.07} & \multicolumn{2}{|c|}{4.23} & NS & \multicolumn{2}{|c|}{3.55} & \multicolumn{2}{|c|}{4.25} & 8.50 & \multicolumn{2}{|c|}{4.85} & \multicolumn{2}{|c|}{7.24} & NS \\
\hline
\end{tabular}

Means of the same category followed by the different letters are significantly different from one another using LSD test $(\mathrm{P} \leq 0.05)$

Table 2. Two years means for standard germination (\%), field emergence (\%) and field emergence index of soybean land races vs improved varieties as affected by sowing dates

\begin{tabular}{|l|c|c|c|}
\hline \multicolumn{1}{|c|}{ Soybean varieties } & $\begin{array}{c}\text { Standard germination } \\
(\mathbf{\%})\end{array}$ & $\begin{array}{c}\text { Field emergence } \\
(\mathbf{\%})\end{array}$ & $\begin{array}{c}\text { Field emergence } \\
\text { index }\end{array}$ \\
\hline Land races & $77.1 \mathrm{a}$ & $61.8 \mathrm{a}$ & $79.2 \mathrm{a}$ \\
\hline Improved varieties & $55.5 \mathrm{~b}$ & $39.0 \mathrm{~b}$ & $71.0 \mathrm{~b}$ \\
\hline Year-I (2004) & 69.2 & 56.6 & 82.0 \\
\hline Year-II (2005) & 67.7 & 48.7 & 70.20 \\
\hline
\end{tabular}

Table 3. Analysis of variance for standard germination (\%), field emergence (\%) and field emergence index of soybean land races vs improved varieties as affected by sowing dates for two years average

\begin{tabular}{|l|l|l|l|l|}
\hline \multicolumn{1}{|c|}{ S.O.V } & D.F & \multicolumn{1}{|c|}{$\begin{array}{c}\text { Germination } \\
(\boldsymbol{\%})\end{array}$} & $\begin{array}{c}\text { Field emergence } \\
(\boldsymbol{\%})\end{array}$ & $\begin{array}{c}\text { Field emergence } \\
\text { index }\end{array}$ \\
\hline Year (Y) & 1 & 84.10 & $2480.63^{* *}$ & $5463.91^{* *}$ \\
\hline Replications (R) & 6 & 76.57 & 195.95 & $429.08^{* *}$ \\
\hline Sowing dates (D) & 3 & $1971.45^{* *}$ & $1879.52^{* *}$ & $533.81^{*}$ \\
\hline YxD & 3 & 28.78 & $855.84 * *$ & $1208.37 * *$ \\
\hline Error I & 18 & 116.66 & 57.02 & 106.04 \\
\hline Varieties (V) & 4 & $4506.70^{* *}$ & $5328.74 * *$ & $1027.14 * *$ \\
\hline Land races vs Improved & $(1)$ & $17759.0 * *$ & $19919.93^{* *}$ & $2528.50^{* *}$ \\
\hline YxV & 4 & 115.37 & 72.85 & 325.42 \\
\hline DxV & 12 & 49.58 & $200.24 * *$ & 264.81 \\
\hline YxDxV & 12 & 58.88 & $142.42^{*}$ & $421.85 *$ \\
\hline Error II & 96 & 73.12 & 73.70 & 211.87 \\
\hline Total & 159 & & & \\
\hline
\end{tabular}

$*=$ Significant at $5 \%$ level of probability

$* *=$ Significant at $1 \%$ level of probability

Field emergence (\%)

Field emergence means for years, sowing dates (D), varieties (V) and $\mathrm{D} x \mathrm{~V}$ interaction 
were significantly different for the two years average (Table 1). Field emergence in 2004 was 16\% higher than 2005 planted crop. Seeds from the April planted crop gave the highest field emergence $(60.2 \%)$ followed by May planted crop. Field emergence significantly declined in seeds obtained from June (47.6\%) and July (46.2\%) planted crops. The greater field emergence of seeds from early planted crop could be attributed to availability of longer growing period for dry matter accumulation, seed development, seed filling and proper maturation in comparison to the seeds from late planted crop and thus our findings are in total agreement concerning, Field emergence $\%$ age [8].

The highest field emergence $(66.1 \%)$ was recorded in Kulat brown followed by Kulat white, while the lowest field emergence (38.4\%) was recorded in Swat-84 followed by NARC-II. Field emergence of improved varieties observed was significantly lower by $36.9 \%$ than the land races (Table 2). It was further noted that Field emergence of land races decreased gradually from $73.9 \%$ in seeds from April planted crop to $51.9 \%$ in seeds of July planted crop. However in case of improved varieties this decline was noted as negligible. The higher field emergence of land races may be due to the smaller seed size associated with slow deterioration with respect to the large seeded improved varieties. Substantial differences in field emergence means within years (crop seasons) and within sowing date [10].

The interaction between $\mathrm{DxV}$ indicated that Kulat brown, Kulat white and Mothi showed gradual decrease in field emergence when sowing was delayed from April to July. Kulat brown, Kulat white and Mothi field emergence were decreased at the rate of -7.22 , -6.13 and -8.86 respectively when sowing were delayed from April to July, while improved varieties (NARC-II and Swat-84) showed slight decreased at the rate of -0.375 and -1.175 respectively (Figure 1 ).

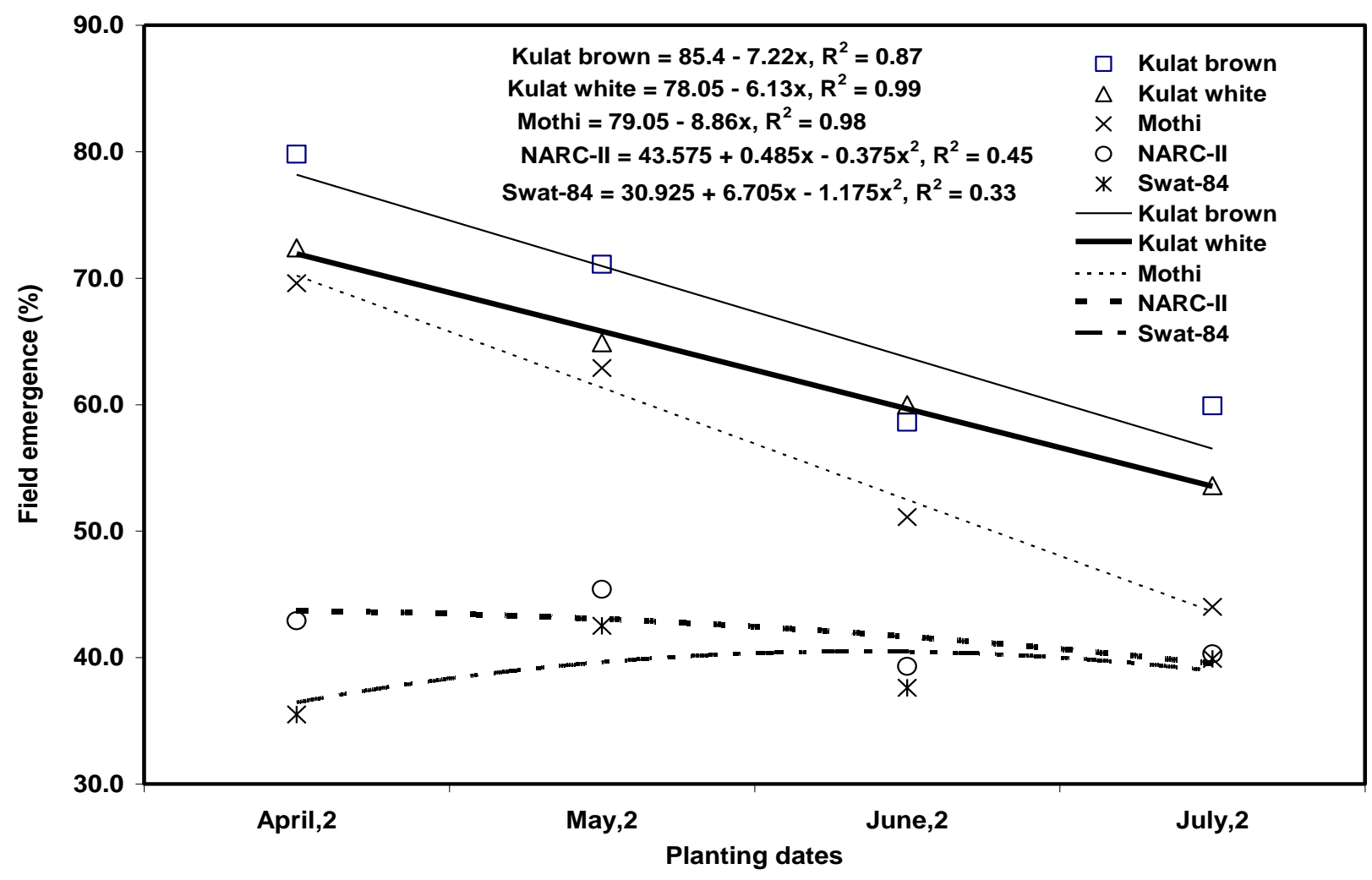

Fig 1. Field emergence (\%) of soybean varieties as affected by planting dates 


\section{Field emergence index (FEI)}

Statistical analysis of the two years average revealed, that emergence index of seeds was significantly affected by years (crop seasons), sowing dates (D) and varieties (V). (Table 1) Emergence index values for soybean planted in 2004 were $18 \%$ higher relatively to 2005 planted crop. Maximum emergence index (79.1) was recorded in seeds from April planted crop followed by seeds from July planted crop. Lowest emergence index (70.9) was recorded in seeds from June planted crop. Emergence index of seeds from May planted crop though higher than emergence index of seeds from June planted crop, however, equal to the emergence index of seeds as noted from April and July planted crops.

The highest emergence index (83.6) was noticed in seeds of Kulat brown, followed by emergence index of seeds due to Kulat white. The lowest emergence index (70.8) was recorded for seeds in case of Swat-84. Thus far emergence index of land races was observed greater than improved varieties (Table 2).

Emergence index was not affected by D x V interaction. Emergence index was based on the standard germination and the performance of the seeds in the field. The more adequate the field conditions, like moisture, temperature and soil preparation, the higher the emergence index. This technique has successfully been used [10] for comparison of the seeds of the same seed lot under different sowing dates. Methods of determining emergence index were also [10] using different techniques.

\section{Conclusion}

Standard germination, field emergence and field emergence index declined when sowing was delayed from April to July. Maximum Field emergence (60.2) and Field emergence index (79.1) were recorded in April planted seeds. More seeds germinated (74.1) when seeds planted on May. Land races showed stable and maximum standard germination, field emergence and field emergence index than improved varieties in different sowing dates.

\section{Authors' contributions}

Performed \& designed the experiments: A Muhammad \& Inamullah, Contributed reagents \& Reference section: $\mathrm{H}$ Khan Wrote the paper: A Muhammad \& M Arif.

\section{References}

1. MINFAL (2006). Agricultural Statistics of Pakistan. Ministry of Food, Agriculture and Livestock, Economic Wing, Govt of Pakistan, Islamabad.

2. Khaliliaqdam N, Afshin S, Naser L \& Farshid GF (2010). Seed vigor and field performance of soybean seed lots case study: northern areas of Iran. AmericanEurasian J Agric \& Environ Sci 12 (2): 262-268.

3.Torres RM, Roberval DV \& Maristela P (2004). Accelerated aging and seedling field emergence in soybean. Sci Agric (Piracicaba, Braz.) 61(5): 476-480.

4. Pourhadian H \& Khajechpour MR (2012). Relationship between germination tests and field emergence of wheat. Asian $J$ App Sc 3 (2): 160-165.

5. Keigley PJ \& Muller RE (1986). Changes in soybean seed quality from high temperature during seed fill and maturation. Crop Sci 26: 1212-1216.

6. Khalil SK, Maxal JG \& Murray LW (2001). Soybean seed matured on different dates affect seed quality. Pak $J$ Biol Sci 4: 365-370,

7. Ajirloo AR, Shaban M \& Moghanloo GD (2013). Effect of priming methods on emergence and seedling growth of maize (Zea mayze L.). Intl J Farm \& Alli Sci 2(18): 658-661.

8. Kolasinska K, Szyrmer J \& Dul S (2000). Relationship between laboratory seed quality tests and field emergence of common bean seed. Crop Sci 40: 470475 . 
9. Basra AS, Dhillon R \& Malik CP (1989). Influence of seed treatment with plant growth regulators on metabolic alterations of germinating maize embryos under stressing temperature regimes. Annu Rev Bot 64: 37-41.

10. Torres RM, Vieira RD \& Panobianco M (2004). Accelerated aging and seedling field emergence in soybean. Sci Agric 61: 476-480.

11. M. Asim, Shad KK, Amir ZK \& Nisar A (2016). Response of soybean varieties to maturity and biomass production under various planting dates. Pure Appl Biol 5(3): 4 18-425.

12. Ali M, Abdur R, Jawad A, Husain A, Sikandar H, Kashif W, Anwar R, Waqas A \& Haji M (2016). Influence of transplanting dates and population densities on the growth and yield of onion. Pure Appl Biol 5(2): 345-354.

13. Imran, Izaz H, Shahida N, Salim S, Aziz U R, Hayat Z, Inayat U, Asad AK \& Subhan U (2016). Growth and yield of Maize hybrids as affected by different sowing Dates in Swat Pakistan. Pure Appl Biol 5(1): 114-120.

14. Anonymous (1999). International Rules for Seed Testing. International Seed
Testing Association, Seed Sci Technol 27(supplement): 47-50.

15. Steel RGD, Torrie JH \& Dicky DA (1997). Principles and procedures of statistics, a biometrical approach, 3rd Edn, McGraw Hill, Inc. Book Co, New York.

16. Uem \& Unioeste (2003). Sowing seasons and quality of soybean seeds. Scientia Agricola 60: 245-252.

17. Rahman, MM, Hampton JG \& Hill MJ (2006). Soybean seed yield as affected by time of sowing in a cool temperature environment. J New Seeds 7: 1-15.

18. Khan AZ (2001). Influence of planting date and plant density on canopy temperature, seed development, seed quality and yield of soybean. $\mathrm{Ph}$. D Dissertation, University of Agriculture, Faisalabad.

19. Ranal MA \& Santana DG (2006). How and why to measure the germination process. Rev Brasil Bot 29: 1-11.

20. Rice KJ \& Dyer AR (2001). Seed aging, delayed germination and reduced competitive ability of Bromus tectorum. Plant Ecol 155: 237-243. 